worlds, though he was anticipated in this by Thomas Digges.

THE recent issue of Polish Science and Learning (London: Oxford University Press) is devoted to articles dealing with the life and work of Copernicus, prepared in connexion with the quatercentenary celebrations held earlier this year. One of these is by Sir Harold Spencer Jones, the Astronomer Royal (see Nature, May 22, p. 573); another, by Prof. H. Dingle, was referred to in the same issue (p. 576). In addition, Prof. St. Kot has contributed an address entitled "The Cultural Background of Copernicus", which shows how greatly indebted Copernicus was to the University of Cracow for his cultural polish. From letters written at the time, we learn that his university life was spent in an atmosphere which favoured independence of thought, enthusiasm for research, and provided the opportunities for developing universal, unfettered personalities. Mathematics and astronomy were predominant in the University, and humanist poetry also took a prominent place. Cracow was the only university north of the Alps in the fifteenth century which had two chairs of astronomy, and several of Copernicus's fellow-students devoted themselves to the study of astronomy and geography. Although he carried out prolonged studies after leaving Cracow in Bologna, Rome, Ferrara, and Padua, the University of Cracow was the first to take an approving interest in his discovery, and the professors there were the first to use Copernicus's astronomical calculations.

H. Kucharzyk has an article entitled "The First Disciples of Copernicus in England (Early English Coperniciana)", which deals with the evolution of astronomy in England in the second half of the sixteenth century. The first English scientific man who was a real adherent and ardent supporter of the Copernican idea was Thomas Digges (1546-59), whowas known as an astronomer and also as one of the leading mathematicians of Elizabethan times. His work, "A Perfit Description ...", which appeared in $\mathbf{1 5 7 6}$, is regarded as the principal English treatise on the Copernican system printed before the second quarter of the seventeenth century. H. Kucharzyk has also a short article with the title "Copernicus as Economist, Statesman, and Poet", and shows Copernicus's knowledge of monetary questions. In his treatise "De Monetæ Cudendæ Ratio", published in 1526, he formulated the principle which was later known as Gresham's Law, that bad money in circulation with good will drive out the good. His work in political spheres, as a physician, administrator, commanderin-chief of the beleaguered city of Olsztyn, and also as a poet, is dealt with very briefly in this article.

\section{Mass Asphyxia}

$\mathrm{I}_{\mathrm{N}}$ the tube shelter disaster in March of this year 173 people ( 28 men, 83 women and 62 children) lost their lives as the result, not of enemy action, but of a woman's fall with a child as the crowd was entering the shelter in a reasonably orderly manner. 0thers fell on top of the woman and the child, and within a few seconds there was a pile of people 3-4 ft. high. Some three hours later all casualties had been cleared. Some people at the top of the pile were dead, some at the bottom were living. Almost the last person extricated was a girl of about seven, who walked to the first aid post without help. These facts and many more of interest are given by Dr. K.
Simpson (Lancet, September 11, 1943) in what he claims to be the first detailed scientific record of this very rare type of accident. The paper records the results of autopsies done on the instructions of the Coroner on four selected cases and discusses the causes of the deaths. Simpson points out that the factors causing sudden deaths in the early stages of asphyxia are little recognized; such deaths are usually accidental or due to criminal action and can scarcely be reproduced for quiet physiological experiment.

The causes of the deaths of these people were found to be complex. The author points out that asphyxia is not a simple problem. The word means pulseless (from the Greek, a-sphuxis), and not prevention of breathing. Three of the cases autopsied showed changes quite out of keeping with prolonged asphyxia. Among other factors that may operate in such accidents are direct compression of the abdomen or chest, constriction of the neck, concussional head injuries, inhalation of vomit and "emotional, reflex neurogenic, local cardiac and more general tissue changes". Parallel factors operate in criminal strangulation and the author discusses these. People may die suddenly at the sight of approaching death or danger or even when they receive bad news or anticipate asphyxia. Impaction of food at the glottis or of water in drowning, garotting, strangling, blows or kicks on the neck, even a brisk eurrent of cold air on the neck, may, in certain individuals, stimulate the carotid sinus reflex and, through this, may cause vasovagal arrest of respiration and the circulation. Bruises and violent hyperextension of the neck, inhalation of vomit, crushing of the chest or abdomen and similar injuries had occurred in the cases autopsied. The author adduces evidence of the rapidity with which local biochemical changes in the heart muscle and in the blood chemistry may occur in asphyxia. When some or all of the factors indicated above are operating together, death can occur very quickly, perhaps within thirty seconds. Apart from the public and biological interest of this paper, it should have, as the author indicates, considerable forensic value.

\section{International Bird Preservation}

A JorNT meeting of the British and Polish Sections of the International Committee for Bird Preservation was held in the hall of the Royal Geographical Society on September 25 with Mr. David Seth-Smith in the chair. Dr. Jul. Borucki, representing the Polish Section, spoke on the work for bird preservation done in the past in Poland, directing attention to the fact that Poland and Czechoslovakia set an example to the world by the establishment of the international reserve in the High Tatras. He spoke of the work of reconstruction which would be needed after the War and the peculiar problems of bird preservation which would have to be faced. In a message, Count Wodzicki, chairman of the Polish Section (now Consul-General in New Zealand) stressed the close links which had always existed between the British and Polish Sections; links which had been made closer by the British Section adopting the Polish Section for the duration of the War, an act which symbolized a tribute to the Polish naturalists who had not only lost property and all the results of their scientific work but also their lives.

Mr. Walter E. Higham showed his magnificent colour film of British birds. He took his representa- 
tive and international audience all over Great Britain, showing in the most exquisite photography different types of landscapes and the birds that are found there: from a typical English garden to the moors and mountains of Scotland, the Lake District, wood. lands, fields and hedgerows, the fens, sandy shores and rocky coasts-a film which indeed demonstrates the glories of Britain to the foreigner and should justly make any Briton proud. About thirty species of birds were represented, all of such beauty that it is difficult to make any special mention, but the shots of a shelduck feeding in a shallow pool and reflected in the water are perhaps the highest achievement gained by any Nature photographer. The Belgian Ambassador, in moving a vote of thanks to $\mathrm{Mr}$. Higham, stressed the value of international cooperation in Nature preservation; he mentioned in particular the International Conference on the Preservation of the Fauna of Africa and the proposed conference for the preservation of the fauna of the Pacific, which had to be abandoned on the outbreak of war.

\section{A Part-time Education Scheme}

WE have received a copy of an illustrated booklet which is handed to every boy on entering the service of W. T. Henley's Telegraph Works Co., Ltd., and Henley's Tyre and Rubber Co., Ltd. This booklet outlines a scheme which is intended to enable all youths joining the Henley organization to see how they can train themselves for their careers. Every boy is given the option of undertaking a course of training extending over a period of years. 'Those who have shown that they can benefit from such privileges and have been accepted for the course are released one day a week from their normal works duties to attend approved classes at selected educational institutions near to their place of employment. They are expected to devote themselves wholeheartedly to the courses laid down for them during this day, and to attend a recognized educational establishment of their own choosing on at least one other evening in the week, for which purpose, wherever practicable, they will be released from shift-work or overtime. In addition, they must undertake to carry cut the homework in connexion with their day course to the satisfaction of the education authorities. The subjects selected for the day periods are of a more serious and fundamental nature, but a good deal of freedom is given in the selection of subjects for the evening courses. Boys are paid for the time spent at the day establishment, and all fees, both for the day and evening courses, are paid by Henley's. The scheme is intended to produce better workmen, foremen and managers, and also better citizens; in addition to every encouragement being given to the boys to enlarge their mental outlook, physical training classes form an important part of the scheme.

\section{Production of Crop Seeds}

THE supply and distribution of seeds of agricultural and horticultural crops has been a problem of major concern since 1939 for countries isolated from Central Europe. The developments that have taken place in their attempt to achieve self-sufficiency in this respect are described in Joint Publication No. 5 issued by the Imperial Bureaux, "The Production of Seed of Root Crops and Vegetables" (price 3s.). The creation of the sugar beet industry in the United States market is perhaps the most complete of the accounts published, for it ean now meet domestic needs, whereas during 1932-34 dependence on imported seed was absolute. Good results have been obtained with vegetable seed production in Sweden, and provided the right areas are selected the prospect seems promising in Australia, New Zealand and Canada. As regards Great Britain considerable progress has been made, and although Scotland appears to be outside the limits of economic seed production for all but a few vegetable crops, in England the chief advances lie in determining those areas where maximum seed yield can be expected. An interesting development is the investigation into the possibilities afforded by the tropical highlands and by those parts of the Empire which lie in the Mediterranean basin. Much information is provided on the varieties used, seed laws and regulations, and a useful index of crops and varieties is appended. Specialists or members of recognized scientific institutions who are in need of more complete references to the literature on any given section, or of more detailed information on special points, are invited to apply to the Imperial Agricultural Bureaux at East Malling, Aberystwyth or Cambridge.

\section{Earthquakes in Central and South America}

The United States Coast and Geodetic Survey, in co-operation with Science Service and the Jesuit Seismological Association, has found the epicentres of three recent earthquakes in Central and South America. The first, on June 30, occurred at $20 \mathrm{~h}$. $13.0 \mathrm{~m}$. U.T. from an epicentre near lat. $14 \cdot 5^{\circ} \mathrm{S}$., long. $74^{\circ} \mathrm{W}$., which is just north of the town of Coracora in Peru. The focus may have been deeper than normal. The second, on July 4 , occurred at $9 \mathrm{~h} .52 \cdot \mathrm{lm}$. U.T. from an epicentre near lat. $9^{\circ}$ N., long. $84 \cdot 5^{\circ} \mathrm{W}$., which is near the coast south-east of the town of San José, and due south of the volcano Irazu in Costa Rica. The depth of focus in this instance was possibly $100 \mathrm{~km}$. The third earthquake was on July 5 at $2 \mathrm{Ih}$. $7 \cdot 6 \mathrm{~m}$. U.T. from an epicentre lat. $17 \cdot 5^{\circ} \mathrm{S}$., long. $73^{\circ} \mathrm{W}$., which is immediately off the coast west of the town of Mollendo in Peru. The depth of focus was normal. All these epicentres are in well-known seismic areas and all interpretations and determinations are tentative. Calculations were based on instrumental reports from the seismological observatories at Georgetown, Weston, St. Louis, Pasadena, Philadelphia, Fordham, Tucson, San Juan, Washington D.C., Burlington, Mobile, Buffalo, and Salt Lake City.

\section{Parsons Memorial Lecture}

The Parsons Memorial Fund, which is administered by the Royal Society, made provision for a memorial to the late Hon. Sir Charles Parsons in Westminster Abbey, and for an annual Parsons Lecture to be given under the auspices of eight specified institutions and societies in turn which are concerned with the subjects most closely associated with Parsons' name. In accordance with the terms governing the appoint. ment of the lecturers, the 1943 lecture, which is the eighth of the series, is to be given under the auspices of the Physical Society. It will be delivered at the meeting of the Society at the Royal Institution at 4.30 p.m. on October 15, by the Right Hon. Lord Rayleigh, who has chosen as his subject "Optical Topics, in part connected with Charles Parsons". Previous lectures have dealt more especially with other aspects of Parsons' work. 